\title{
On the relationship between total ozone and atmospheric dynamics and chemistry at mid-latitudes - Part 2: The effects of the El Niño/Southern Oscillation, volcanic eruptions and contributions of atmospheric dynamics and chemistry to long-term total ozone changes
}

\author{
H. E. Rieder ${ }^{1, *}$, L. Frossard ${ }^{2}$, M. Ribatet ${ }^{2, * *}$, J. Staehelin ${ }^{1}$, J. A. Maeder ${ }^{1}$, S. Di Rocco ${ }^{1,3}$, A. C. Davison ${ }^{2}$, T. Peter ${ }^{1}$, \\ P. Weihs ${ }^{4}$, and F. Holawe ${ }^{5}$ \\ ${ }^{1}$ Institute for Atmospheric and Climate Science, ETH Zurich, Zurich, Switzerland \\ ${ }^{2}$ Mathematics Institute for Analysis and Applications, EPF Lausanne, Lausanne, Switzerland \\ ${ }^{3}$ Department for Geography, University of Zurich, Zurich, Switzerland \\ ${ }^{4}$ Institute of Meteorology, University of Natural Resources and Life Sciences (BOKU), Vienna, Austria \\ ${ }^{5}$ Department for Geography and Regional Research, University of Vienna, Vienna, Austria \\ *now at: Lamont-Doherty Earth Observatory and Department of Applied Physics and Applied Mathematics, \\ Columbia University, New York, NY, USA \\ ** now at: Institute of Mathematics and Mathematical Modeling, University Montpellier II, Montpellier, France
}

Correspondence to: H. E. Rieder (hr2302@columbia.edu)

Received: 30 January 2012 - Published in Atmos. Chem. Phys. Discuss.: 25 May 2012

Revised: 5 November 2012 - Accepted: 28 November 2012 - Published: 8 January 2013

\begin{abstract}
We present the first spatial analysis of "fingerprints" of the El Niño/Southern Oscillation (ENSO) and atmospheric aerosol load after major volcanic eruptions (El Chichón and Mt. Pinatubo) in extreme low and high (termed ELOs and EHOs, respectively) and mean values of total ozone for the northern and southern mid-latitudes (defined as the region between $30^{\circ}$ and $60^{\circ}$ north and south, respectively). Significant influence on ozone extremes was found for the warm ENSO phase in both hemispheres during spring, especially towards low latitudes, indicating the enhanced ozone transport from the tropics to the extra-tropics. Further, the results confirm findings of recent work on the connection between the ENSO phase and the strength and extent of the southern ozone "collar". For the volcanic eruptions the analysis confirms findings of earlier studies for the northern mid-latitudes and gives new insights for the Southern Hemisphere. The results provide evidence that the negative effect of the eruption of El Chichón might be partly compensated by a strong warm ENSO phase in 1982-1983 at southern mid-latitudes. The strong west-east gradient in
\end{abstract}

the coefficient estimates for the Mt. Pinatubo eruption and the analysis of the relationship between the AAO and ENSO phase, the extent and the position of the southern ozone "collar" and the polar vortex structure provide clear evidence for a dynamical "masking" of the volcanic signal at southern mid-latitudes. The paper also analyses the contribution of atmospheric dynamics and chemistry to long-term total ozone changes. Here, quite heterogeneous results have been found on spatial scales. In general the results show that EESC and the 11-yr solar cycle can be identified as major contributors to long-term ozone changes. However, a strong contribution of dynamical features (El Niño/Southern Oscillation (ENSO), North Atlantic Oscillation (NAO), Antarctic Oscillation (AAO), Quasi-Biennial Oscillation (QBO)) to ozone variability and trends is found at a regional level. For the QBO (at 30 and $50 \mathrm{hPa}$ ), strong influence on total ozone variability and trends is found over large parts of the northern and southern mid-latitudes, especially towards equatorial latitudes. Strong influence of ENSO is found over the Northern and Southern Pacific, Central Europe and central 
southern mid-latitudes. For the NAO, strong influence on column ozone is found over Labrador/Greenland, the Eastern United States, the Euro-Atlantic Sector, and Central Europe. For the NAO's southern counterpart, the AAO, strong influence on ozone variability and long-term changes is found at lower southern mid-latitudes, including the southern parts of South America and the Antarctic Peninsula, and central southern mid-latitudes.

\section{Introduction}

Since the detection of the Antarctic ozone hole in the late 1980s (Farman et al., 1985), interest in total ozone changes has increased strongly in the scientific community and general public, due to the direct link with changes in biologically active UV radiation (e.g., Calbó et al., 2005).

Multiple linear regression models including independent variables, also called explanatory variables or covariates, which represent atmospheric variability have been used to assess and analyze the attribution to long-term total ozone trends. The most commonly-used covariates include: the 11-yr solar cycle, the Quasi-Biennial Oscillation (QBO), (linear) trends attributed to anthropogenic ozone depleting substances (ODS), and atmospheric aerosol load after volcanic eruptions (e.g., Fioletov et al., 2002; Steinbrecht et al., 2006; Vyushin et al., 2007; Schnadt Poberaj et al., 2011; WMO, 2003, 2007, 2011). In addition variables describing decadal/long-term climate variability, like, e.g., the El Niño/Southern Oscillation (ENSO), the Arctic Oscillation (AO), the North Atlantic Oscillation (NAO), and the Antarctic Oscillation (AAO), have been included in such analyses.

There is broad agreement within the scientific community that negative long-term ozone trends at mid-latitudes between the 1980s and mid-1990s are dominated by changes in ODS, while short-term changes are attributable to dynamical phenomena such as horizontal advection and convergence of mass related to changes in tropospheric and lower stratospheric pressure systems (e.g., Wohltmann et al., 2007; Mäder et al., 2007; Koch et al., 2005).

However, several recent studies have shown that atmospheric dynamics have had and still have a significant, and larger than previously thought, influence on total ozone changes: (i) according to Hood and Soukharev (2005), Wohltmann et al. (2007), Mäder et al. (2007), and Harris et al. (2008), dynamics may account for about one-third or even more of the total ozone decline observed between the 1980s and mid-1990s; (ii) the observed increase in column ozone since the late 1990s (at northern mid-latitudes) can be mainly attributed to dynamical changes (e.g., Harris et al., 2008; WMO, 2007); and (iii) the change in the atmospheric burden in ODS contributed insignificantly to the increase in column ozone in recent years (e.g., Hood and Soukharev,
2005; Harris et al., 2008; Shepherd, 2008; Hegglin and Shepherd, 2009).

The analysis of spatial "fingerprints" of the 11-yr solar cycle, QBO, ODS, NAO, and AAO at mid-latitudes is presented in the companion paper (Frossard et al., 2013, from here on referred to as Part 1). Here we give a complementary discussion of the spatial "fingerprints" and effects of volcanic eruptions and ENSO on ozone extremes and mean values. Additionally we analyze the contribution of individual dynamical and chemical covariates on long-term total ozone changes for several regions of interest at northern and southern midlatitudes.

\section{Data and methods}

\subsection{Total ozone data}

In this study we used the NIWA assimilated total ozone data set (version 2.7; spatial resolution of $1.25^{\circ}$ longitude by $1.0^{\circ}$ latitude; temporal resolution: daily averages) for the time period 1979-2007. The NIWA data set is homogenized; drifts between measurements of different satellite instruments have been corrected through inter-satellite instrument comparison and comparison with data from Dobson and Brewer groundbased instruments, which contribute to the Global Atmosphere Watch Program (GAW) of the World Meteorological Organization (WMO) (see http://www.bodekerscientific. com/data/total-column-ozone). For further details on the NIWA assimilated total ozone data set we refer to Part 1 and Bodeker et al. (2005), Müller et al. (2008), and Struthers et al. (2009).

\subsection{Indices describing atmospheric dynamics and chemistry}

The 11-yr solar cycle, QBO at 30 and $50 \mathrm{hPa}$ levels, ozone depleting substances (ODS) in terms of equivalent effective stratospheric chlorine (EESC), the North Atlantic Oscillation Index (NAO) and its southern counterpart the Antarctic Oscillation Index (AAO), the Nino 3.4 Index, representing the El Niño/Southern Oscillation, and the Sato Index describing atmospheric aerosol load after the volcanic eruptions of El Chichón and Mt. Pinatubo have been used to describe the state of the atmosphere and atmospheric dynamics and chemistry in this study. An overview of the temporal evolution of these indices and their sources is provided in the companion paper by Frossard et al. (2013).

\subsection{Statistical models}

Extremes and mean values in total ozone and their relation to important covariates are analyzed on a grid cell basis using two different types of statistical models: (i) a model based on extreme value theory (EVT) for the analysis of extreme low and high total ozone values (termed ELOs and 
EHOs, respectively); and (ii) an autoregressive moving average (ARMA) model for monthly mean values of total ozone.

Since these models are the same as in Part 1, they are only briefly described here; see Part 1 for more details. We start with a motivation for our modeling approach, then describe the common structure of models (i) and (ii) that includes the covariates, and finally report the individual characteristics of the two models.

The distinction between models for extremes and mean values is essential because of the different nature of these types of data, according to their situation in the tails or in the "bulk" of the statistical distribution function. Nevertheless, we include the same covariate-dependent expression into both models, in order to compare the effects of the covariates on total ozone EHOs, ELOs, and mean values.

Even though the NIWA ozone data are spatial, we fit univariate models to each grid cell separately, mainly because spatial models for extremes that are computationally feasible for massive data sets are still not very well developed. Our approach is not optimal since it neglects the joint spatial behavior of ozone, but compared to averaging over zonal bands, it has the advantage of naturally addressing non-stationarity in space and time.

The covariates are included through a multiple linear regression term $\mathbf{Z}(t) \boldsymbol{\beta}(x)$ consisting of a purely timedependent design matrix $\mathbf{Z}(t)$, which is the same for all grid cells, and an individual coefficient vector $\boldsymbol{\beta}(x)$ for each grid cell $x$. The design matrix is composed of seasonality terms and covariates describing chemical and dynamical processes in the atmosphere (see Sect. 2.2 and Part 1). An exploratory analysis in the framework of extremes showed that the most suitable choice of covariates is

$$
\begin{aligned}
\mathbf{Z}(t) \boldsymbol{\beta}(x)= & \beta_{0}(x)+\sum_{i=1}^{3}\left(\beta_{2 i-1}(x) \cos \left(\frac{2 \pi t}{\varphi_{i}}\right)\right. \\
& \left.+\beta_{2 i}(x) \sin \left(\frac{2 \pi t}{\varphi_{i}}\right)\right)+\beta_{7}(x) \operatorname{EESC}(t) \\
& +\beta_{8}(x) \operatorname{SOLAR}(t)+\beta_{9}(x) \mathrm{QBO}_{30}(t) \\
& +\beta_{10}(x) \operatorname{QBO}_{50}(t)+\beta_{11}(x) \operatorname{ENSO}(t) \\
& +\beta_{12}(x)\left\{\begin{array}{l}
\operatorname{AAO}(t) \\
\operatorname{NAO}(t)
\end{array}\right\}+\beta_{13}(x) \operatorname{CHICHON}(t) \\
& +\beta_{14}(x) \operatorname{PINATUBO}(t)
\end{aligned}
$$

where the $\varphi_{i}$ allow for 1-yr, 6-month, and 4-month seasonalities, i.e., $\left(\varphi_{1}, \varphi_{2}, \varphi_{3}\right)=(12,6,4)$. For each model, we estimate the vector $\boldsymbol{\beta}(x)$ separately at every grid cell $x$ by maximum likelihood estimation (briefly explained in Sect. A1 of Part 1) and produce maps of the estimates of each component $\beta_{i}$ for interpretation and comparison.

Standard errors of the estimates $\hat{\beta}_{i}$ are easily obtained from the numerical optimization procedure. From likelihood theory it is known that the estimate divided by its standard error has an asymptotically Gaussian distribution with unit variance and mean proportional to the true value of the pa- rameter. This result allows us to assess the significance of the estimates by a so-called $z$-test. For every covariate $i$, we test whether its coefficient $\beta_{i}$ is zero in a particular grid cell; if this hypothesis is rejected, the covariate is said to have a significant influence on total ozone in that grid cell. As with any statistical hypothesis test, rejection is based on the $p$-value, which can for our case be oversimplified to the probability that the estimate obtained is consistent with the true $\beta_{i}$ being zero. A small $p$-value (here chosen as $\leq 1 \%$ ) suggests that estimate is significantly non-zero. For a more formal description of the $z$-test and $p$-values, see Sect. A2 of Part 1 . We perform such $z$-tests for every grid cell and produce maps of the $p$-values, as for the coefficient estimates.

Evaluation of different temporal resolutions of the models (an annual and a seasonal model, see Part 1) by likelihood ratio tests showed that the seasonal model is preferable. Therefore some covariates are split into four parts, one for each of the seasons December-January-February, March-AprilMay, June-July-August, and September-October-November. For example $\beta_{7}(x) \operatorname{EESC}(t)$ in Eq. (1) can be replaced by

$$
\begin{aligned}
& \beta_{7, \text { spring }}(x) \operatorname{EESC}_{\text {spring }}(t)+\beta_{7, \text { summer }}(x) \operatorname{EESC}_{\text {summer }}(t) \\
& +\beta_{7, \text { fall }}(x) \operatorname{EESC}_{\text {fall }}(t)+\beta_{7, \text { winter }}(x) \operatorname{EESC}_{\text {winter }}(t),
\end{aligned}
$$

where $\mathrm{EESC}_{\diamond}$ equals the EESC values for the months of season $\diamond$ and equals zero for the other months.

Statistical models for extreme events only describe the tail of the probability distribution and are therefore fitted merely to a subset of "extreme" observations whose definition depends on the specific model. For ozone extremes, we chose the so-called $r$-largest order statistics model (see Part 1 and Coles, 2001, Sect. 3.5), where the data are divided into blocks and just the $r$ largest (for EHOs) or smallest (for ELOs) observations of each block are used in the fitting procedure. The covariates are incorporated in the location parameter $\mu$, accounting at the same time for the temporal non-stationarity of the data. At grid cell $x$, the location parameter is

$\mu(x, t)=\mathbf{Z}(t) \boldsymbol{\beta}(x)$,

where the right-hand side is given by Eq. (1). The time index $t$ stands for the block length, which has been set to one month, meaning that the covariates are also at a monthly resolution. Details on this and on our choice of $r=3$ are given in Part 1.

For total ozone mean values we use an autoregressive moving average (ARMA) process (see Part 1 or Brockwell and Davis, 2002), which is a flexible model for stationary time series. We use this model because the monthly mean values are autocorrelated. The importance of correlations when analyzing atmospheric data is briefly discussed in Sect. 3.2.1 of Part 1. If $Y(x, t)$ denotes the mean value of month $t$ at grid cell $x$, we fit an ARMA process to the stationarized sequence

$\eta(x, t)=Y(x, t)-\mathbf{Z}(t) \boldsymbol{\beta}(x)$, 

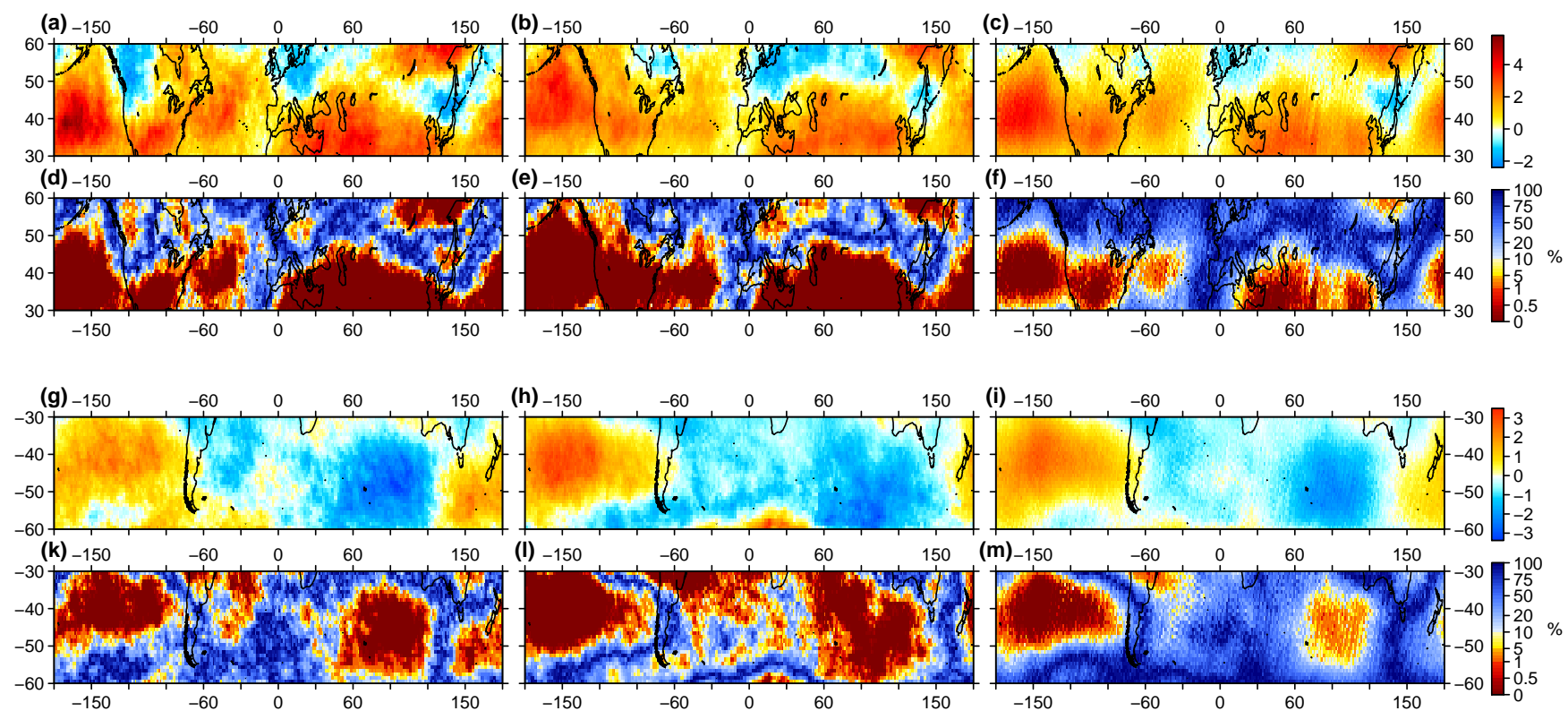

Fig. 1. Pointwise regression coefficient estimates (in DU (unitENSO) ${ }^{-1}$ ) for the El Niño/Southern Oscillation on an annual basis for (a) EHOs, (b) ELOs, and (c) mean values of total ozone at $30^{\circ} \mathrm{N}$ to $60^{\circ} \mathrm{N}$; (d)-(f) show the $p$-values of pointwise significance tests for the estimates in (a)-(c). (g)-(m) as (a)-(f) but at $30^{\circ} \mathrm{S}$ to $60^{\circ} \mathrm{S}$. An augmented version of this figure including standard errors for all coefficient estimates is provided in Fig. S1.

where the expression of $\mathbf{Z}(t) \boldsymbol{\beta}(x)$ is again given by Eq. (1). An $\operatorname{ARMA}(1,1)$ process was found to be appropriate, i.e.,

$\eta(x, t)=\phi(x) \eta(x, t-1)+\varepsilon(x, t)+\theta(x) \varepsilon(x, t-1)$,

where $\phi(x)$ and $\theta(x)$ are parameters describing the autocorrelation, which is not of primary interest here, and $\varepsilon(x, t)$ is Gaussian white noise.

For further details on all these aspects and models, model validation, as well as a sensitivity analysis on several corrections for multiple testing, we refer to Part 1 of this paper (Frossard et al., 2013).

\section{Results}

In Part 1 it was shown that the spatial analysis confirmed findings of previous studies (e.g., Steinbrecht et al., 2006) concerning the significant influence of the 11-yr solar cycle, QBO, and EESC on column ozone at mid-latitudes on large spatial scale. Further the relationship between modes describing decadal/long-term climate variability (i.e., the NAO and AAO) and total ozone was discussed in detail in Part 1.

Here we focus specifically on the relationship between total ozone extremes and mean values and volcanic eruptions (El Chichón, Mt. Pinatubo) and ENSO. Further, we analyze the contribution of individual covariates to long-term total ozone changes for specific regions of interest at northern and southern mid-latitudes.

\subsection{El Niño/Southern Oscillation (ENSO)}

The El Niño/Southern Oscillation (ENSO) phenomenon is triggered by the large contrast between high tropical and low extra-tropical Pacific sea surface temperatures (Brönnimann et al., 2004a,b). Previous studies (e.g., Trenberth et al., 1998; Alexander et al., 2002) have shown that stratospheric transport processes, the Hadley circulation and Rossby wave generation in the Northern Pacific, are strongly influenced by the ENSO phase. Earlier work reported that strong warm ENSO events are also associated with more frequent stratospheric warmings (e.g., Labitzke and van Loon, 1999; van Loon and Labitzke, 1987), stronger wave activity fluxes, and a strengthened meridional circulation in the middle atmosphere, all contributing to yield a weaker polar vortex and enhanced transport of ozone-rich air from the tropics to the extra-tropical regions (Newman et al., 2001; Randel et al., 2002). However, a recent study by Butler and Polvani (2011) showed that the frequency of occurrence of sudden stratospheric warmings is similar during El Niño and $\mathrm{La}$ Niña events, contrasting with earlier work and indicating similar importance of both ENSO phases for the stratosphere.

The $p$-values in Figs. 1-3 show that ENSO has significant influence on total ozone over large parts of the mid-latitudes. While coefficient estimates are significant at lower midlatitudes, they tend to turn insignificant towards high latitudes (from approximately $50^{\circ} \mathrm{N}$ and $50^{\circ} \mathrm{S}$ ). This spatial pattern might be interpreted as a consequence of enhanced transport of ozone-rich air from the tropics to the extra-tropics 

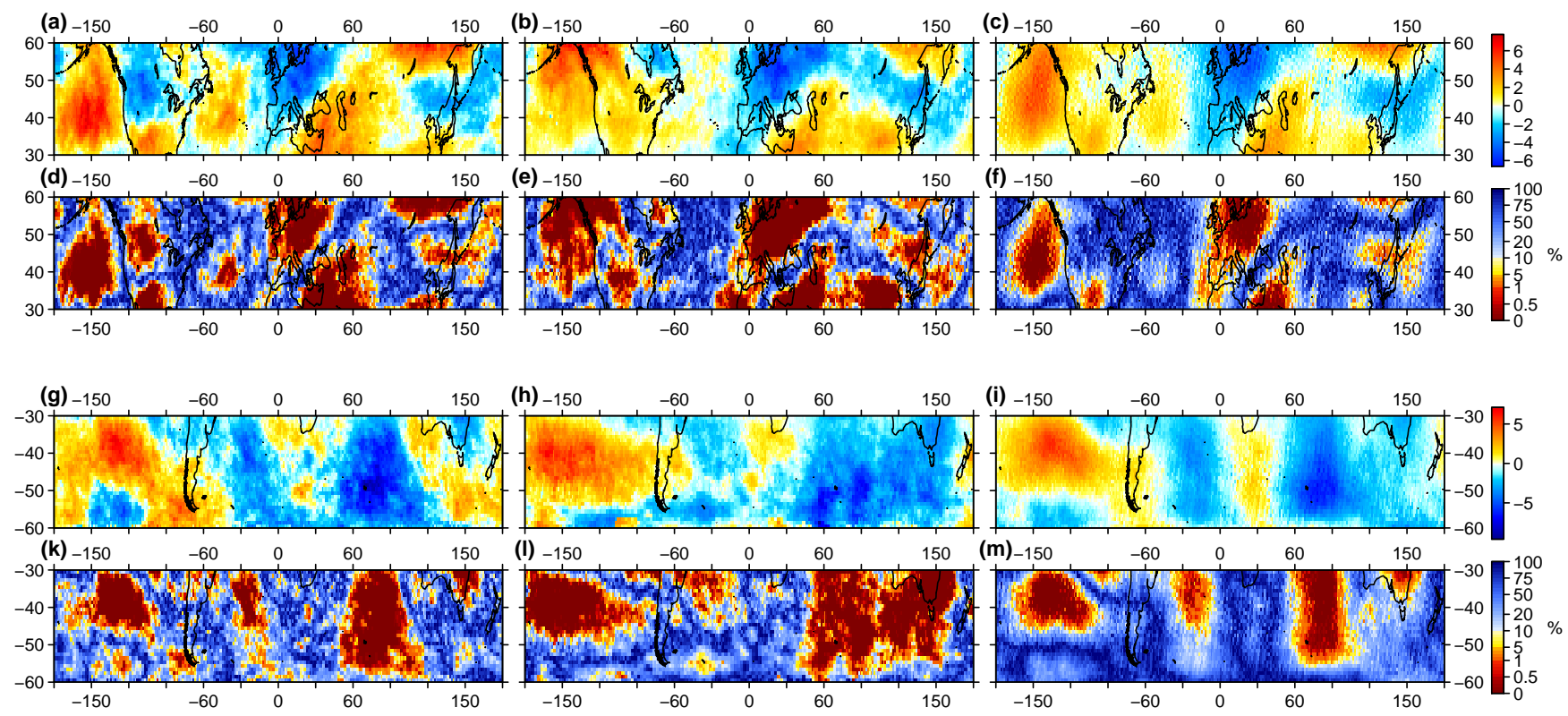

Fig. 2. Pointwise regression coefficient estimates (in DU (unitENSO) ${ }^{-1}$ ) for the El Niño/Southern Oscillation for (a) EHOs, (b) ELOs, and (c) mean values of total ozone during winter (DJF) at $30^{\circ} \mathrm{N}$ to $60^{\circ} \mathrm{N}$; (d)-(f) show the $p$-values of pointwise significance tests for the estimates in (a)-(c). (g)-(m) as (a)-(f) but during winter (JJA) at $30^{\circ} \mathrm{S}$ to $60^{\circ} \mathrm{S}$. An augmented version of this figure including standard errors for all coefficient estimates is provided in Fig. S2.
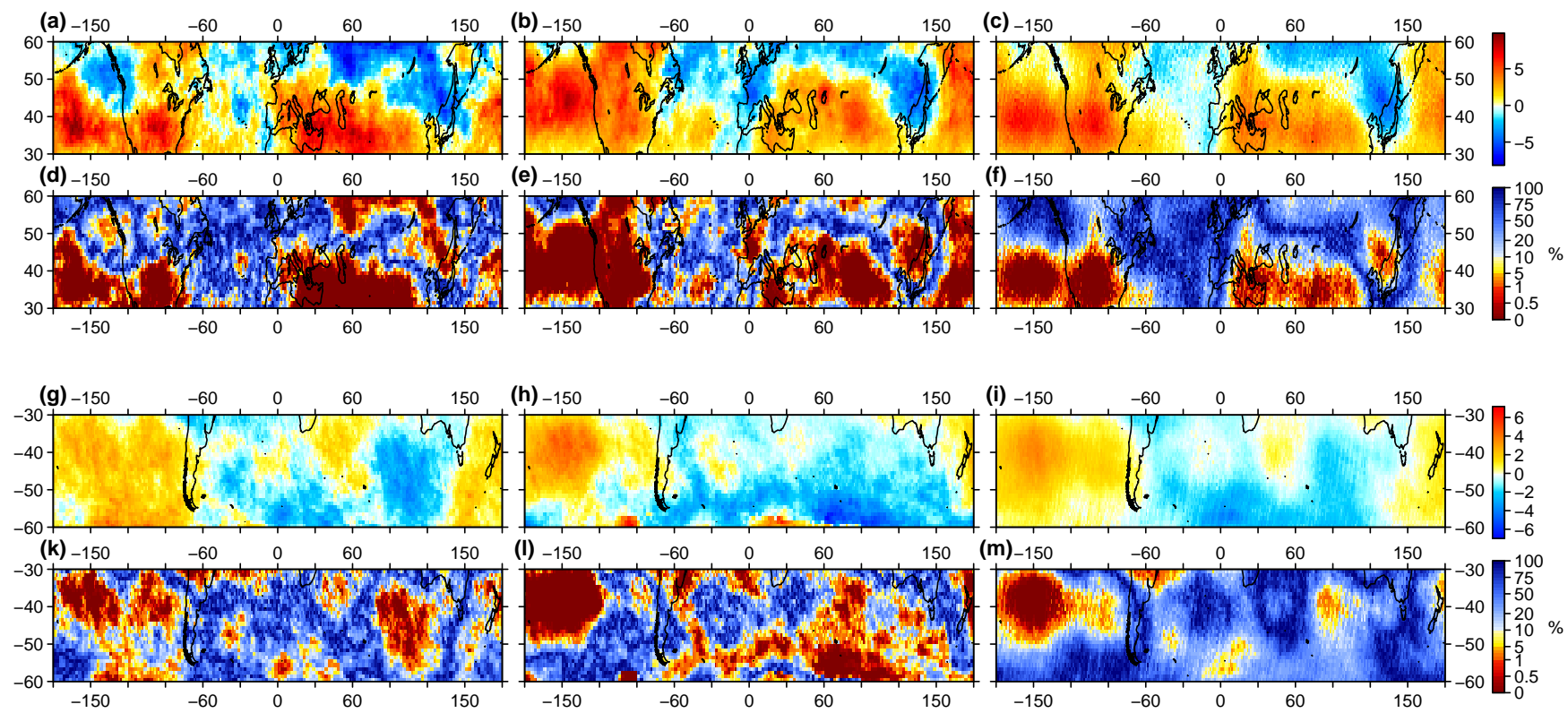

Fig. 3. Pointwise regression coefficient estimates (in DU (unitENSO) ${ }^{-1}$ ) for the El Niño/Southern Oscillation for (a) EHOs, (b) ELOs, and (c) mean values of total ozone during spring (MAM) at $30^{\circ} \mathrm{N}$ to $60^{\circ} \mathrm{N}$; (d)-(f) show the $p$-values of pointwise significance tests for the estimates in (a)-(c). (g)-(m) as (a)-(f) but during spring (SON) at $30^{\circ} \mathrm{S}$ to $60^{\circ} \mathrm{S}$. An augmented version of this figure including standard errors for all coefficient estimates is provided in Fig. S3. 
during warm ENSO events with a strong east-west gradient. While ozone transport is enhanced during the warm phase of the ENSO (El Niño events), it is reduced during its cold phase (La Niña events). Especially over the Northern and Southern Pacific, the estimates are strongly positive, revealing the connection between ENSO, the Hadley cell circulation, and Rossby wave generation. Over Central Europe, significant influence of moderate and strong El Niño events is found during winter (see Fig. 2) and spring (see Fig. 3), which confirms earlier findings on ozone enhancement in the European Sector during the warm ENSO phase (Brönnimann et al., 2004a,b; Rieder et al., 2010a,b, 2011).

Another interesting feature is that highly significant negative ENSO coefficient estimates are found during austral winter and spring over the Indian Ocean, in particular for the extremes (EHOs and ELOs) while less striking for mean values. This spatial pattern can be explained as connection between the southern ozone "collar" and strong El Niño and La Niña events (see Figs. 4 and S4). Due to changes in transport of ozone-rich air from the tropics towards polar regions (during the La Niña phase) the gradient between the polar vortex and mid-latitudes is increased, thereby leading to a shift and local/regional enrichment of the ozone "collar" in the Southern Hemisphere (during winter and spring), visible in the coefficient estimates and $p$-values in Figs. 2 and 3. Our sensitivity analysis (see Part 1) showed that the anticipated shrinkage of the significant areas is less pronounced in the northern mid-latitudes, where the effect of the ENSO persists even under very conservative correction methods.

Our results are in good agreement with recent work of Hitchman and Rogal (2010a,b) reporting on the influence of the ENSO phase on Southern Hemisphere column ozone during the winter to spring transition. Hitchman and Rogal (2010b) report an eastward progression of the Southern Hemisphere maximum ozone from August to October during La Niña compared to El Niño due to differences in general circulation features related to changes in planetary wave patterns in temperature and geopotential height. During August Hitchman and Rogal (2010b) report a positive anomaly over the Southern Pacific and a negative anomaly south of Australia during El Niño (compare with Figs. 4 and S4 of this analysis), and vice versa during the La Niña phase. During the El Niño phase this pattern is related to (i) a strong Australian High stretching southwestwards across the Southern Indian Ocean and (ii) a South African High extending southwestwards across the Atlantic to the southern tip of South America. On the other hand during the La Niña phase a distinct Southern Indian Ocean High is the dominant dynamical feature. In September Hitchman and Rogal (2010b) report a distinct ozone anomaly near South Africa related to an upper-troposphere-lower-stratosphere (UTLS) anticyclone over South Africa during the El Niño phase (compare with Figs. 4 and S4 of this analysis), leading to stronger poleward transport of subtropical ozone-poor air out of the lower stratosphere. During October Hitchman and Rogal (2010b)

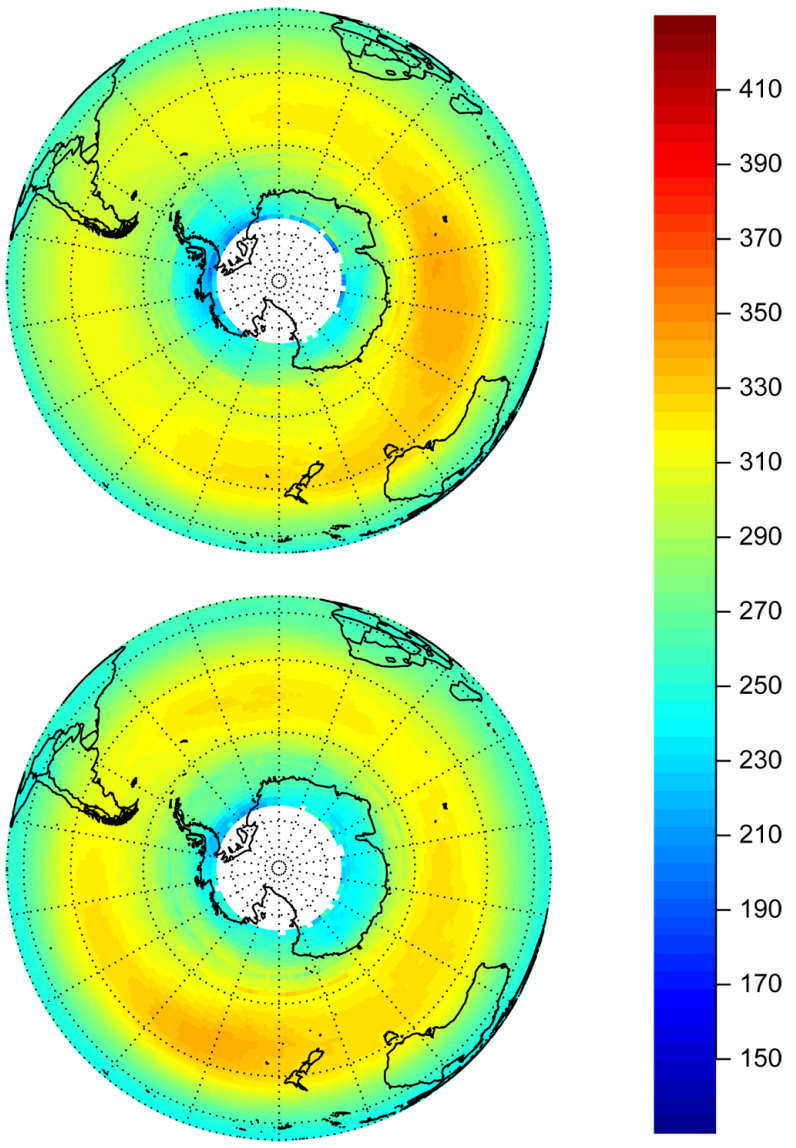

Fig. 4. Southern Hemisphere seasonal mean column ozone (in DU) during austral winter (JJA) for 1986-1989. Top: seasonal mean of 1988 and 1989 representing a strong La Niña phase (shifted, partly opened and locally enriched ozone "collar"). Bottom: seasonal mean of 1986 and 1987 representing a strong El Niño phase (closed, ozone-rich and homogeneous ozone "collar").

describe an ozone maximum south of Australia during the La Niña phase related to a wave one anomaly. The UTLS anticyclone over the subtropical Indian Ocean is enhanced, which leads to a more intense and zonally confined subtropical westerly jet (Hitchman and Rogal, 2010b), and net to more ozone in the "collar" region. Further, Lin et al. (2009) reported that the eddy components of temperature and ozone trends at southern high latitudes are dominated by zonal wavenumber- 1 structures. Especially for October and November they found an interesting pattern relating to the ozone asymmetry, namely departures from the zonally symmetric state, in relation with gradual warming over the subpolar region and Australia, effectively shifting the wave pattern eastward.

\subsection{Volcanic eruptions}

Violent volcanic eruptions can inject large amounts of gaseous compounds (including $\mathrm{SO}_{2}$ and $\mathrm{H}_{2} \mathrm{~S}$ ) into the 

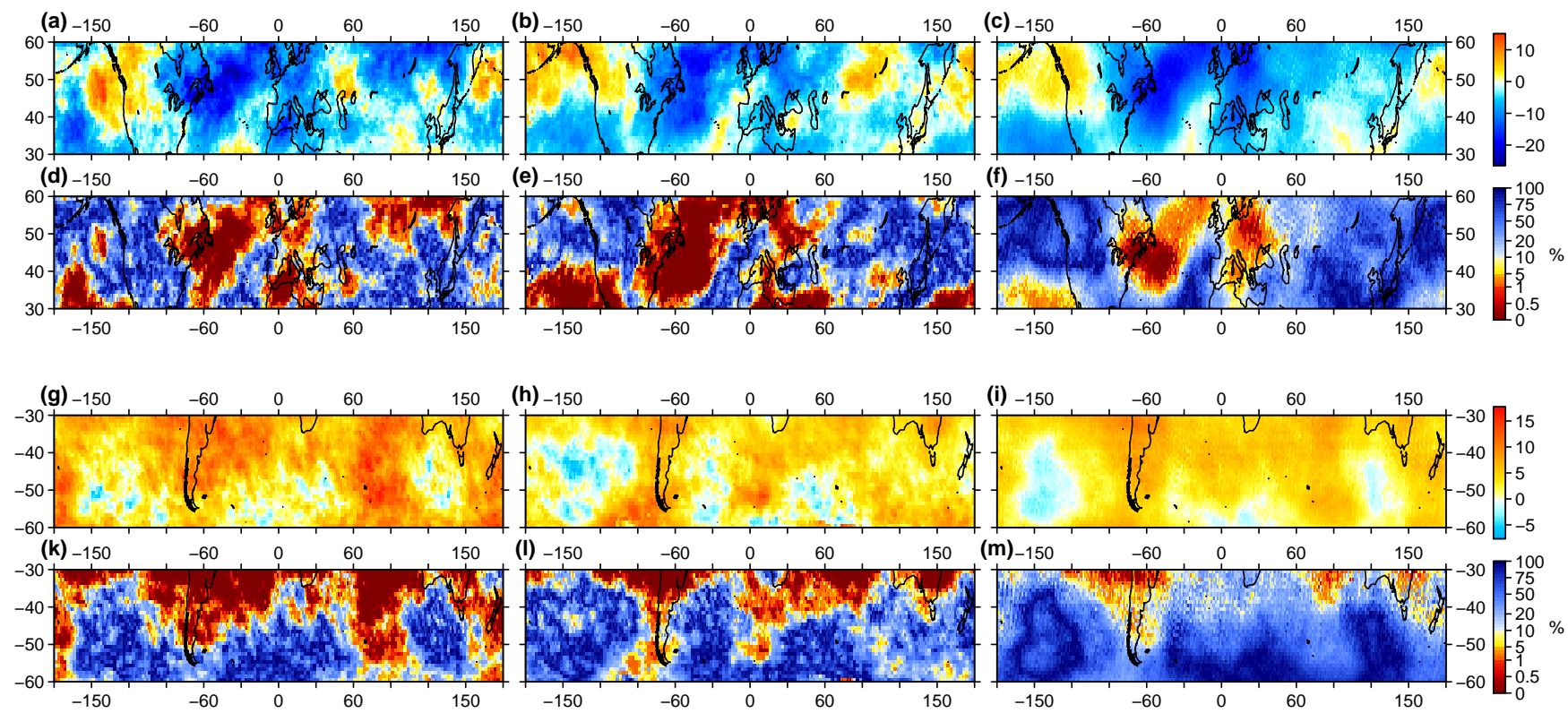

Fig. 5. Pointwise regression coefficient estimates (in DU (unit Sato Index) ${ }^{-1}$ ) for the volcanic eruption of El Chichón on an annual basis for (a) EHOs, (b) ELOs, and (c) mean values of total ozone at $30^{\circ} \mathrm{N}$ to $60^{\circ} \mathrm{N}$; (d)-(f) show the $p$-values of pointwise significance tests for the estimates in (a)-(c). (g)-(m) as (a)-(f) but at $30^{\circ} \mathrm{S}$ to $60^{\circ} \mathrm{S}$. An augmented version of this figure including standard errors for all coefficient estimates is provided in Fig. S5.

stratosphere. These compounds are precursors for the atmospheric formation of sulfate aerosol particles, which in turn provide surfaces for heterogeneous processes on polar stratospheric clouds (e.g., Peter, 1997; Solomon, 1999) in the lower stratosphere, enhancing ozone depletion. Additionally, the gaseous compounds absorb infrared radiation leading to a warmer lower stratosphere and thereby enhance stratospheric dynamics and ozone depletion (e.g., Brasseur and Granier, 1992; Kodera, 1994; Hadjinicolaou et al., 1997). Two major volcanic eruptions (El Chichón, March/April 1982; Mt. Pinatubo, June 1991) occurred in the time period analyzed. In our analysis we used the Sato Index (Sato et al., 1993), describing aerosol loading in terms of mean optical thickness, as a proxy for volcanic activity (see also Part 1).

\subsubsection{El Chichón}

The $p$-values in Fig. 5 show that the volcanic eruption of El Chichón seems to have significant influence on total ozone over a substantial part of the northern mid-latitudes. Especially over the Atlantic Sector, Central and Southern Europe, Northern Russia (only for EHOs), the Eastern United States, and the southern parts of the Northern Pacific coefficients are strongly negative (see Fig. 5a-c) and highly significant (see Fig. 5d-f), though the significant area reduces when allowance is made for multiple testing; see Part 1. This is in good agreement with results of previous studies reporting on the negative effect of the eruption on total ozone in the Northern Hemisphere (Staehelin et al., 1998; Fioletov et al., 2002;
Mäder et al., 2007; Wohltmann et al., 2007; Harris et al., 2008; Rieder et al., 2010a,b, 2011). In the Southern Hemisphere the picture is different. The $p$-values in Fig. $5 \mathrm{k}-\mathrm{m}$ suggest that the El Chichón eruption had a significant influence at lower southern mid-latitudes. Significant influence is found in particular for EHOs and ELOs, while the significant area is much smaller for mean values. However, it is puzzling that in contrast to the Northern Hemisphere the coefficients in the Southern Hemisphere are strongly positive (see Fig. $5 \mathrm{~g}-\mathrm{i}$ ). A possible explanation might be that this pattern is a "fingerprint" for infrared heating due to volcanic aerosols (also partly visible towards equatorial latitudes in the Northern Hemisphere). Further the ENSO phase (strong El Niño) in 1982-1983 might contribute to the "masking" of the volcanic signal due to enhanced transport of ozone from the tropics to the extra-tropics. The absence of the El Chichón signal at southern mid-latitudes is in general agreement with other studies (e.g., Fioletov et al., 2002), but the results presented here suggest that one or more dynamical processes (e.g., ENSO, as discussed above) might mask the volcanic signal.

\subsubsection{Mt. Pinatubo}

As shown in Fig. 6 (top panels) the eruption of Mt. Pinatubo had a highly significant effect for both extremes and mean values at northern mid-latitudes (significance level of $1 \%$ almost over the whole region analyzed), though again the significant region shrinks when allowance is made for 

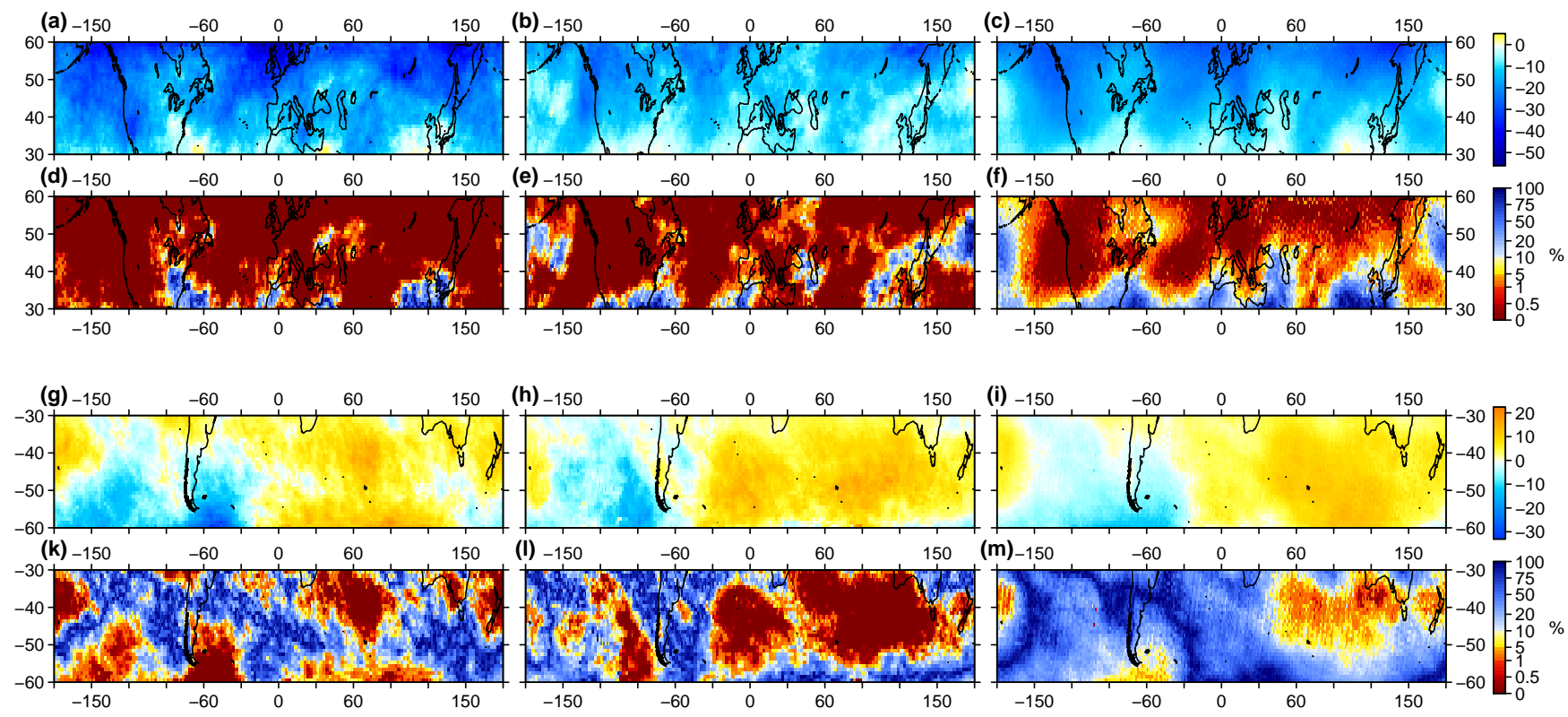

Fig. 6. Pointwise regression coefficient estimates (in DU (unit Sato Index) ${ }^{-1}$ ) for the volcanic eruption of Mt. Pinatubo on an annual basis for (a) EHOs, (b) ELOs, and (c) mean values of total ozone at $30^{\circ} \mathrm{N}$ to $60^{\circ} \mathrm{N}$; (d)-(f) show the $p$-values of the pointwise significance tests for the estimates in (a)-(c). (g)-(m) as (a)-(f) but at $30^{\circ} \mathrm{S}$ to $60^{\circ} \mathrm{S}$. An augmented version of this figure including standard errors for all coefficient estimates is provided in Fig. S6.

multiple testing. Coefficient estimates (Fig. 6a-c) are negative throughout the northern mid-latitudes and increase towards higher latitudes. The strong negative influence of the Mt. Pinatubo eruption found for the northern mid-latitudes is in good agreement with previous studies (Staehelin et al., 1998; Fioletov et al., 2002; Mäder et al., 2007; Wohltmann et al., 2007; Harris et al., 2008; Rieder et al., 2010a,b, 2011; WMO, 2007, 2011).

In contrast, the absence of a clear signal of the Mt. Pinatubo eruption at southern mid-latitudes (WMO, 2003, 2007, 2011; Fioletov et al., 2002) is puzzling, because it is expected that heterogeneous reactions on the volcanic aerosol should lead to chemical ozone depletion (WMO, $2003,2007,2011$ ) as found at northern mid-latitudes. Indeed there is evidence for heterogeneous conversion of chemical species by measurements from New Zealand reporting large enhancements in $\mathrm{HNO}_{3}$ and corresponding reductions in $\mathrm{NO}_{2}$ (Koike et al., 1994). Stolarski et al. (2006), Fleming et al. (2007) and Telford et al. (2009) suggested that there may be dynamical causes for the absence of the Mt. Pinatubo signal at southern mid-latitudes.

In this analysis, the signal found at southern mid-latitudes is not comparable to that for northern mid-latitudes. However, from the $p$-values (see Fig. $6 \mathrm{k}-\mathrm{m}$ ) it seems that this eruption had significant influence, for EHOs and particularly for ELOs, in large parts of the southern mid-latitudes, while hardly any significant influence is found for mean values. Significant coefficient estimates are found for lower latitudes, the Indian Ocean, and parts of the Southern Pa- cific (see Fig. 6g, h). Interestingly the coefficients (for ELOs) show a strong west-east gradient from highly negative (roughly between $160^{\circ} \mathrm{W}$ and $65^{\circ} \mathrm{W}$ ) to highly positive (roughly between $65^{\circ} \mathrm{W}$ and $160^{\circ} \mathrm{W}$ ) values.

Our analysis provides evidence that the suppressed signal of the Mt. Pinatubo eruption in the southern mid-latitudes is of dynamical origin (see below). As stated before, a strong west-east gradient of the coefficient estimates is visible from the results. The strongest positive coefficient estimates are found over the Indian Ocean while the strongest negative ones are found towards the Antarctic Peninsula and poleward over the Southern Pacific. This pattern can be explained as follows: the analysis of the southern polar vortex structure and the corresponding southern ozone "collar" during austral spring, see Figs. 7 and S7, shows that in the time period after the volcanic eruption (1991-1992) (i) the vortex was shifted and elongated towards the Antarctic Peninsula and (ii) the "collar" was richer in ozone than in neighboring years. Further, the maximum ozone area inside the "collar" was shifted (centered over the Indian Ocean) in 1992 in comparison to neighboring years.

Overall the strong ozone "collar" following the Mt. Pinatubo eruption suggests that enhanced transport of ozone to mid-latitudes may have happened, most likely in relation with the concurrent strong warm ENSO phase. Dynamically diabatic descent is responsible for the maintenance of the high ozone mixing ratios inside the ozone "collar". Further this descent also contributes to observed shifts owing to the sloping of the vortex structure. For further 


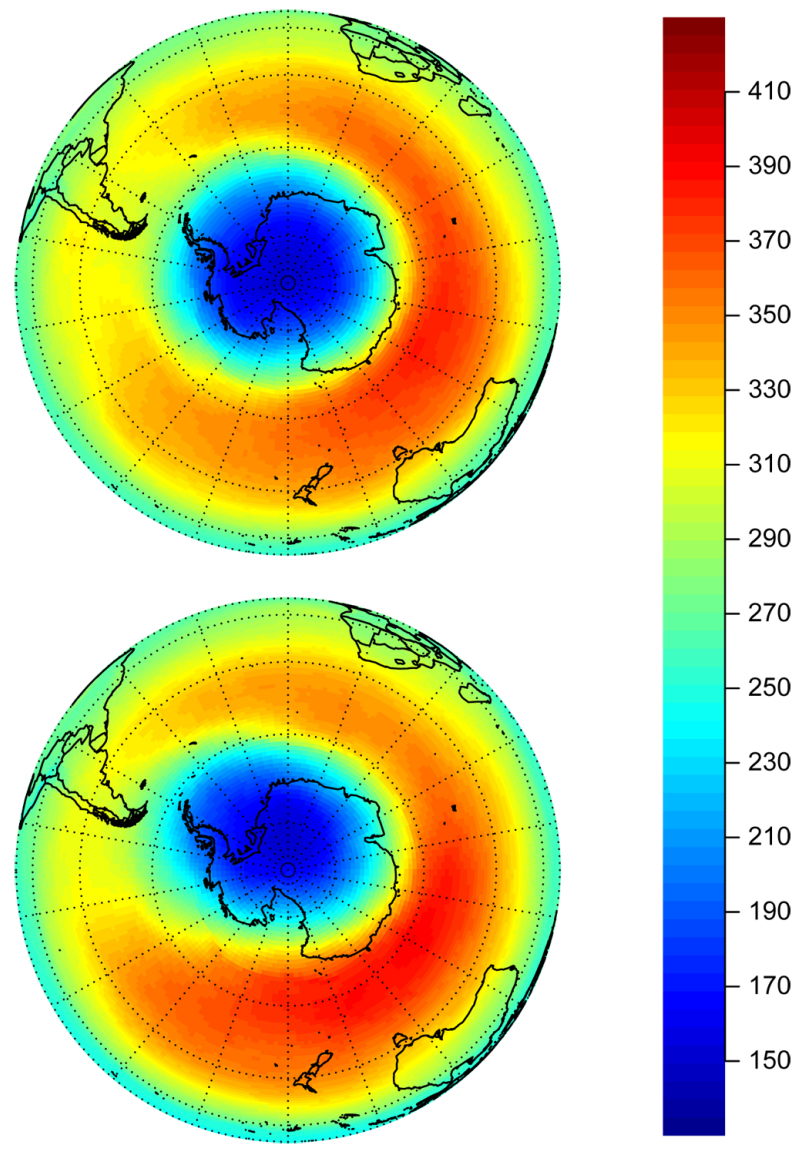

Fig. 7. Southern Hemisphere October mean column ozone (in DU) in 1989-1992. Top: 1989-1990 for pre-Pinatubo eruption period. Bottom: 1991-1992 for the eruption period.

details on these processes, see Mariotti et al. (2000) and references therein. The southern polar vortex was shifted and strengthened due to the low phase of the Antarctic Oscillation (AAO). Figure 8 shows that the average ozone hole area is smaller during the low phase of the AAO, while correspondingly the observed minimum column ozone (which can be seen as a proxy for the ozone hole depth) is higher. Therefore, the strong gradient between the deep ozone hole and rich ozone "collar" can be related to the AAO phase.

It is well known that the extra-tropical circulation in the Southern Hemisphere is driven by the AAO (e.g., Thompson and Wallace, 2000; Thompson and Solomon, 2009; Polvani et al., 2011). During a high phase of the AAO, the Lagrangian mean circulation is strongly reduced and therefore less ozone is transported to mid and high latitudes. This process is closely related to atmospheric wave activity (Thompson and Wallace, 2000). Recently Schnadt Poberaj et al. (2011) analyzed the dynamical state of the atmosphere following the Mt. Pinatubo eruption and its effect on zonal mean column ozone. These authors suggest that ozone depletion caused by the volcanic aerosol was overcompensated by in-
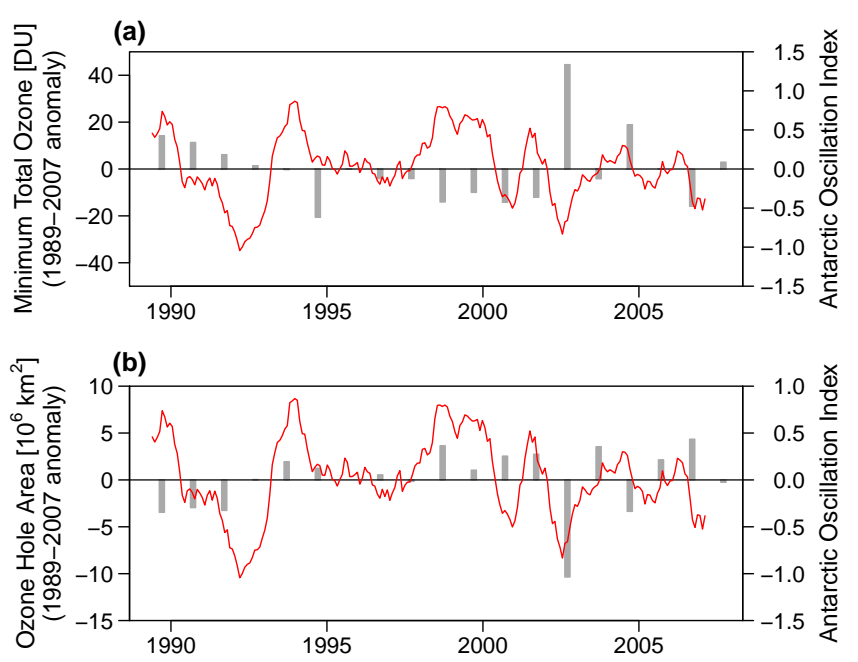

Fig. 8. 13-month averages of the Antarctic Oscillation Index (red) in comparison with (a) the anomaly of the absolute minimum mean column ozone observed between 21 September and 16 October based on the period 1989-2007 (grey bars) and (b) the anomaly of the average area of the southern ozone hole between 7 September and 13 October based on the period 1989-2007 (grey bars). The ozone hole area and minimum mean column ozone are based on TOMS data provided by NASA/GSFC (http://ozonewatch.gsfc. nasa.gov/meteorology/annual_data.html). All panels are for 19892007.

creased ozone transport from the tropics to the southern midlatitudes due to an enhanced stratospheric residual circulation. This enhanced residual circulation results from anomalously large planetary wave activity emanating from the troposphere, caused by preconditioning of the atmospheric flow in association with a combined negative AAO and warm ENSO phase. The results are in good agreement with those presented here and provide dynamical arguments for the formation of the strong southern ozone "collar" and the steep gradient to the shifted polar vortex area "masking" the volcanic effects.

Therefore, the suppression of the Mt. Pinatubo signal at southern mid-latitudes can be explained by a combination of the shift of the polar vortex in 1991 (the first winter after the eruption) towards the southern part of South America; the depth of the ozone hole in 1991-1993; the unusual enrichment of the ozone "collar" due to enhanced transport from the tropics to the extra-tropics, related to the state of the ENSO (especially over the Southern Pacific), the AAO phase (see section above), and to atmospheric wave activity (see Schnadt Poberaj et al., 2011); and the displacement of the maximum ozone rich region of the ozone "collar" over the Indian Ocean in the later phase. The results suggest that the state of the AAO is of major importance for these dynamical patterns. For a further discussion of the relation between $\mathrm{AAO}$ and atmospheric wave activity we refer to Schnadt Poberaj et al. (2011). 
It therefore seems that the coefficient estimates for the Mt. Pinatubo eruption do not merely cover the volcanic effect itself but also capture the dynamical state of the atmosphere following the eruption, thereby leading to an identification of the large scale features responsible for the "masking" of the Mt. Pinatubo signal at southern mid-latitudes. Overall the results suggest, in agreement with earlier work (e.g., Fleming et al., 2007), that the volcanic effect of the eruption is amplified by the dynamical state of the atmosphere in the northern mid-latitudes but is strongly weakened/shaded in the Southern Hemisphere.

\subsection{Contribution of dynamical and chemical features to ozone changes and variability}

In a next step the contribution of the individual covariates (solar cycle, QBO at 30 and $50 \mathrm{hPa}$, EESC, NAO/AAO, ENSO, volcanic eruptions of El Chichón and Mt. Pinatubo) to EHOs, EHOs, and mean values was analyzed based on the coefficient estimates derived from the spatial models. Analysis of the $p$-values for the different covariates highlighted several regions of specific interest (see above and Part 1): the Northern and Southern Pacific, the Eastern United States, the Labrador/Greenland region, the Euro-Atlantic Sector, continental Europe, the southern parts of South America and the Antarctic Peninsula, the central southern mid-latitudes, and the central region of the southern ozone "collar" (South of Australia and New Zealand). For all these regions one representative grid cell was selected to quantify the influence of the individual covariates on EHOs, ELOs, and mean values (see Figs. 9 and 10).

The analysis showed that: (i) throughout all regions, the temporal variability in EESC and the 11-yr solar cycle are the dominating forces modulating total ozone changes (and variability); (ii) there is clear evidence for a strong dynamical contribution (QBO, ENSO, NAO/AAO) to EHOs and ELOs, which is generally more weakly expressed for mean values; (iii) especially for the individual dynamical features, large regional differences in the modulation of EHOs, ELOs, and mean values are found.

Over both the Northern and the Southern Pacific, ENSO is identified as the major modulating force after EESC and the solar cycle (see Figs. 9a-c and 10a-c). This can be explained by increased/decreased ozone transport from the tropics to the extra-tropics during moderate and strong El Niño/La Niña periods, as ENSO is well known to trigger changes in the Hadley cell and Rossby wave generation (e.g., Trenberth et al., 1998; Alexander et al., 2002). Especially the very strong El Niño events (annual ENSO Index >1) of 1982, 1987, 1991-92, 1997, and 2002 and the very strong La Niña events (annual ENSO index $<-1$ ) of 1988 and 1999 show throughout the Pacific region a strong influence on extremes and mean values, compared to the other regions. On a relative scale, the dynamical modulation is larger for EHOs than for ELOs and mean values over the Northern Pacific than over the Southern Pacific. For all other covariates, less pronounced influence on EHOs, ELOs, and mean values was found over the Pacific region.

Over the Eastern United States (see Fig. 9d-f), Labrador/Greenland (see Fig. 9g-i), and the Euro-Atlantic sector (see Fig. 9k-m), NAO contributes significantly to total ozone changes compared to all other dynamical covariates. Due to transport and blocking conditions (i.e., the direction and intensity of the dominant westerly tropospheric jet, e.g., Orsolini and Limpasuvan, 2001; Orsolini and Doblas-Reyes, 2003), the sign of the NAO effect is opposite in the different regions. While during the positive NAO phase ozone is enhanced over Labrador/Greenland and is reduced over the Eastern United States and the Euro-Atlantic sector, the opposite holds during the negative phase. This becomes obvious comparing the results for EHOs, ELOs, and mean values in Fig. 9d-m: the strong positive (annual NAO Index mean > 0.5) NAO phase in 1980, 1982, and 1984-1985 led to a large positive modulation over the Eastern US and the Euro-Atlantic sector (and also over continental Europe, see next paragraph and Fig. 9n-p) while it had significant negative impact over the Labrador/Greenland region. Over all three regions QBO shows significant contributions to ozone changes compared to the Pacific region, but the total modulation of EHOs, ELOs, and mean values by the QBO remains an order of magnitude smaller than those of NAO.

Over continental Europe (see Fig. 9n-p) ENSO, NAO, and $\mathrm{QBO}$ are the dominating dynamical modulation forces. While for both, EHOs and ELOs, ENSO and NAO are found to be the dominating dynamical forces, mean values seem to be influenced by the QBO, ENSO, and NAO in a similar way. Once again especially strong ENSO and NAO events (as described above) are clearly visible in the contribution records.

For the volcanic eruptions of El Chichón and Mt. Pinatubo at northern mid-latitudes the largest (negative) modulation was found over the Euro-Atlantic sector and Continental Europe. Here the volcanic contribution is for extremes about a factor of 2 larger than in the other regions. Interestingly this feature is not preserved for mean values, where the volcanic eruptions show similar influence on large spatial scales and are rather weak compared to dynamical variability.

At lower southern mid-latitudes, including the southern parts of South America and the Antarctic Peninsula (Fig. 10d-f), the temporal evolution of ELOs and EHOs is mainly dominated by EESC, while all other covariates (dynamical ones and solar cycle) are of minor importance. However, it is interesting that AAO and ENSO seem to contribute more to ELOs than to EHOs or mean values in this region. As discussed here and in Part 1 this feature might be explained by the connection between the ENSO and AAO phase and the transport of ozone from the tropics to the extra-tropics (increased ozone transport during low AAO and warm ENSO phases and vice versa).

Over the central southern mid-latitudes (Fig. 10g-i) and the central region of the southern ozone "collar" 


\section{Northern Pacific:}

(a) $140^{\circ} \mathrm{W} 38^{\circ} \mathrm{N}$

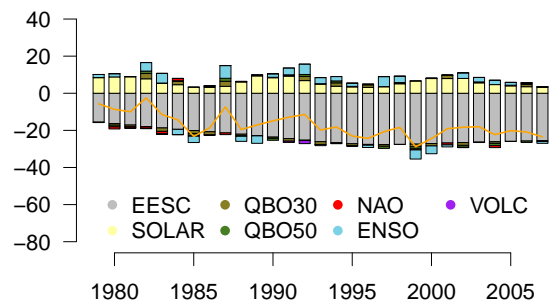

Eastern U.S.:

(d) $75^{\circ} \mathrm{W} 42^{\circ} \mathrm{N}$

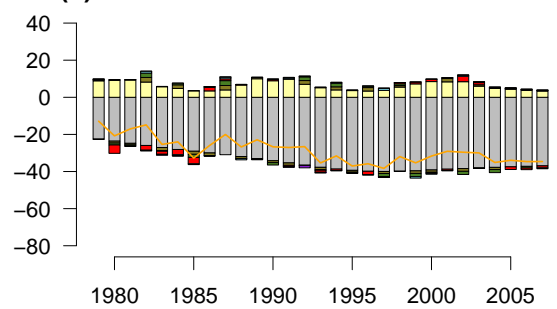

Labrador/Greenland:

(g) $55^{\circ} \mathrm{W} 58^{\circ} \mathrm{N}$

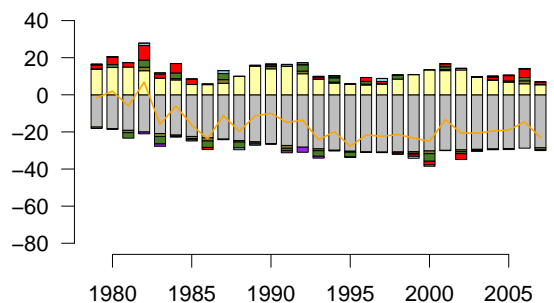

Euro-Atlantic Sector:

(k) $10^{\circ} \mathrm{W} 50^{\circ} \mathrm{N}$

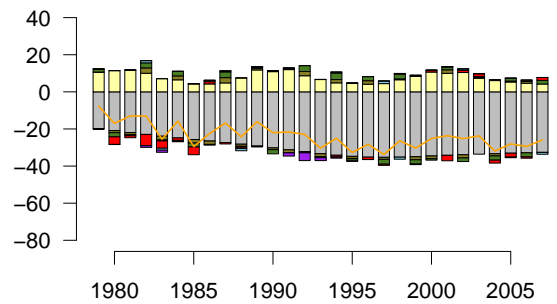

Continental Europe:

(n) $10^{\circ} \mathrm{E} 50^{\circ} \mathrm{N}$

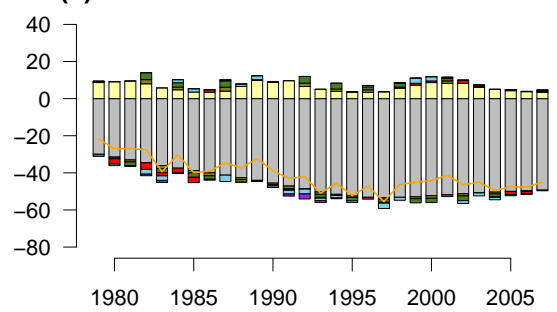

(b) $140^{\circ} \mathrm{W} 38^{\circ} \mathrm{N}$

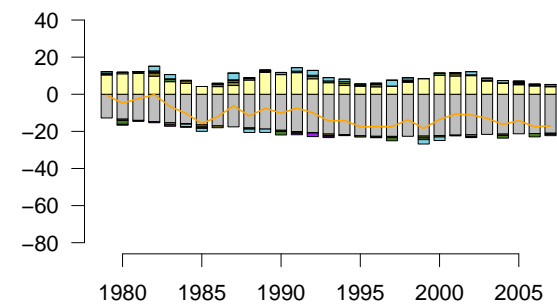

(e) $75^{\circ} \mathrm{W} 42^{\circ} \mathrm{N}$

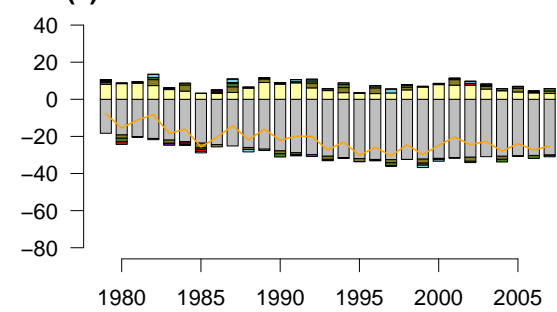

(h) $55^{\circ} \mathrm{W} 58^{\circ} \mathrm{N}$

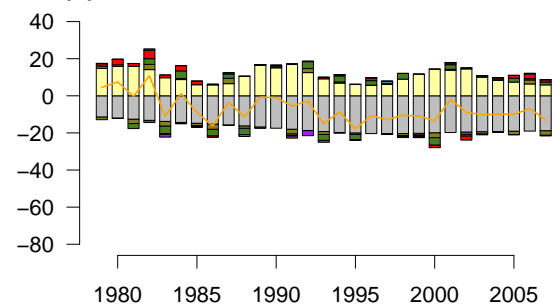

(I) $10^{\circ} \mathrm{W} 50^{\circ} \mathrm{N}$

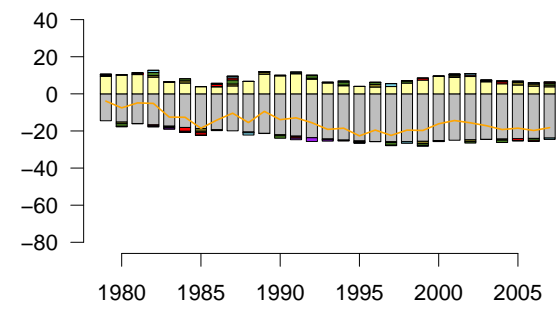

(o) $10^{\circ} \mathrm{E} 50^{\circ} \mathrm{N}$

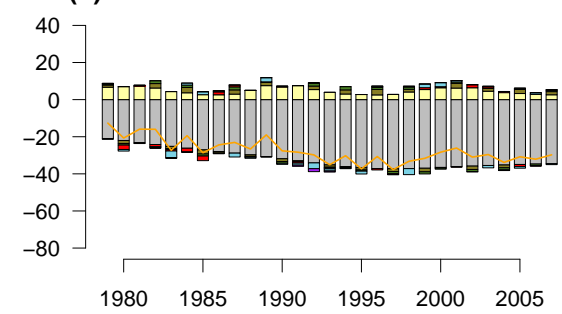

(c) $140^{\circ} \mathrm{W} 38^{\circ} \mathrm{N}$

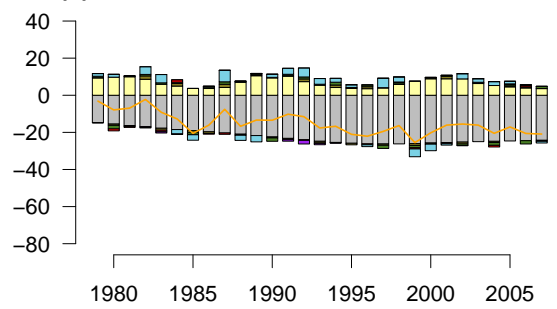

(f) $75^{\circ} \mathrm{W} 42^{\circ} \mathrm{N}$

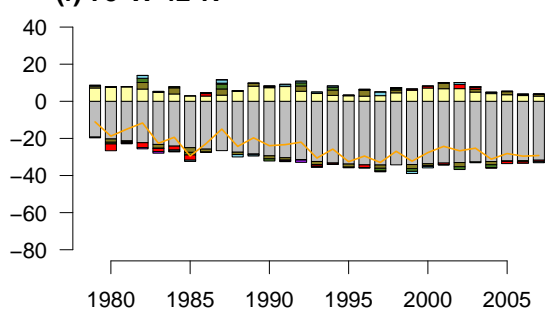

(i) $55^{\circ} \mathrm{W} 58^{\circ} \mathrm{N}$

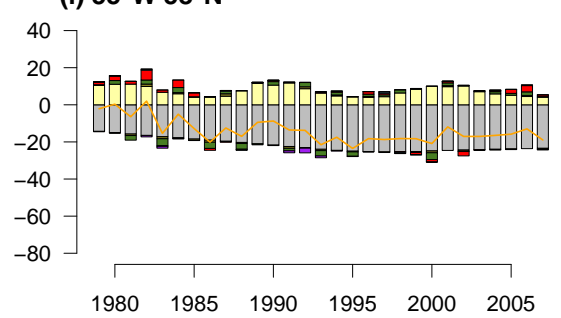

(m) $10^{\circ} \mathrm{W} 50^{\circ} \mathrm{N}$

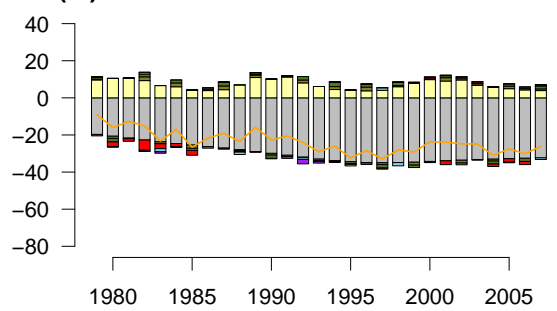

(p) $10^{\circ} \mathrm{E} 50^{\circ} \mathrm{N}$

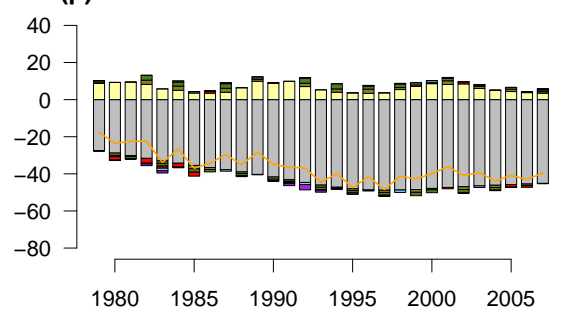

Fig. 9. Contributions of EESC (grey), solar cycle (yellow), QBO at 30 (olive) and $50 \mathrm{hPa}$ (green), NAO (red), ENSO (blue), and volcanic eruptions (purple) to long-term ozone changes (on an annual basis in DU) as derived from the $r$-largest order statistics models for EHOs (left panels (a), (d), (g), (k), (n)), ELOs (middle panels (b), (e), (h), (l), (o)), and as derived from the ARMA model for mean values (right panels (c), (f), (i), (m), (p)) at selected grid cells in the northern mid-latitudes. For convenient reference the solid orange line in panels (a)-(p) gives the net contribution (sum of individual estimates) on an annual basis. 
Southern Pacific:

(a) $140^{\circ} \mathrm{W} 35^{\circ} \mathrm{S}$

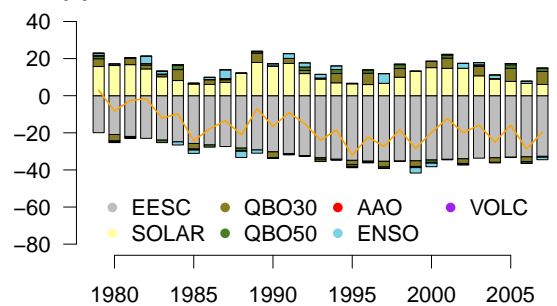

Antarctic Peninsula:

(d) $60^{\circ} \mathrm{W} 56^{\circ} \mathrm{S}$

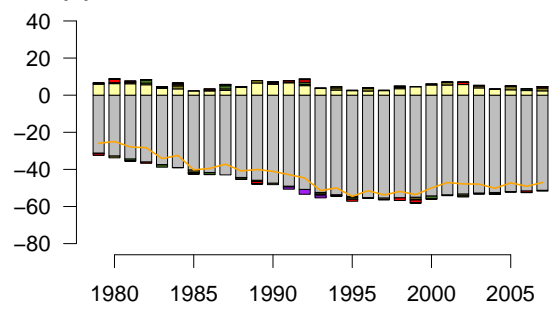

Central Southern Mid-Latitudes:

(g) $65^{\circ} \mathrm{E} 45^{\circ} \mathrm{S}$

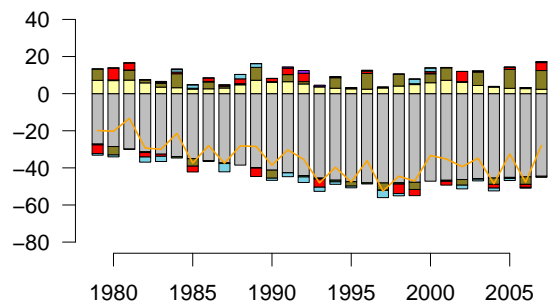

Lower Southern Mid-Latitudes:

(k) $95^{\circ} \mathrm{E} 55^{\circ} \mathrm{S}$

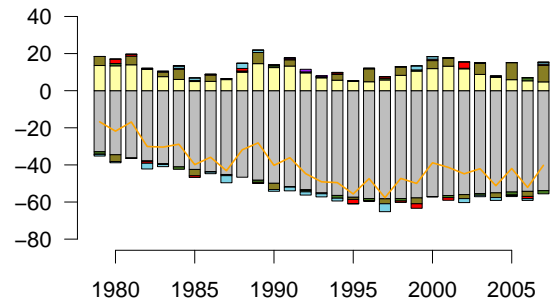

(b) $140^{\circ} \mathrm{W} 35^{\circ} \mathrm{S}$

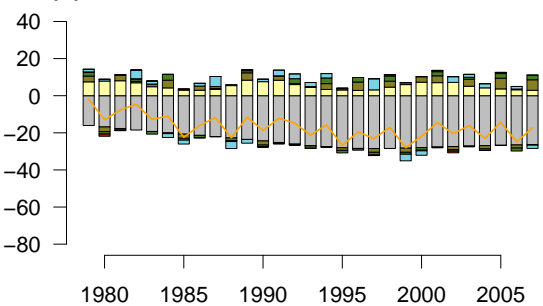

(e) $60^{\circ} \mathrm{W} 56^{\circ} \mathrm{S}$

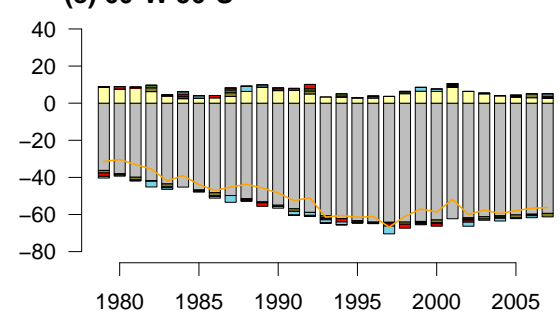

(h) $65^{\circ} \mathrm{E} 45^{\circ} \mathrm{S}$

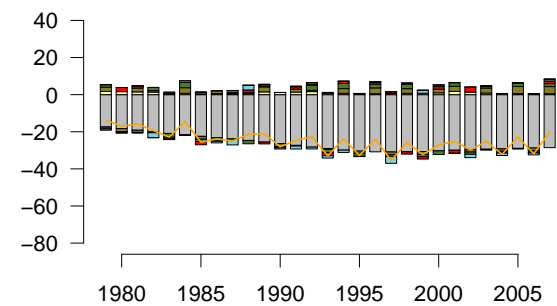

(I) $95^{\circ} \mathrm{E} 55^{\circ} \mathrm{S}$

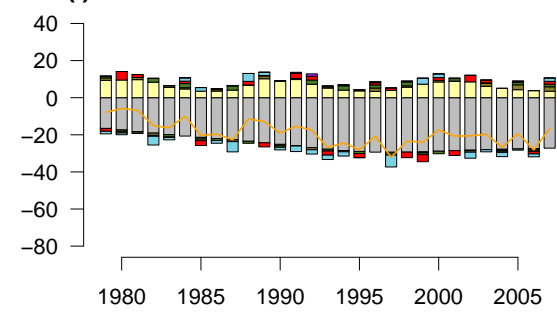

(c) $140^{\circ} \mathrm{W} 35^{\circ} \mathrm{S}$

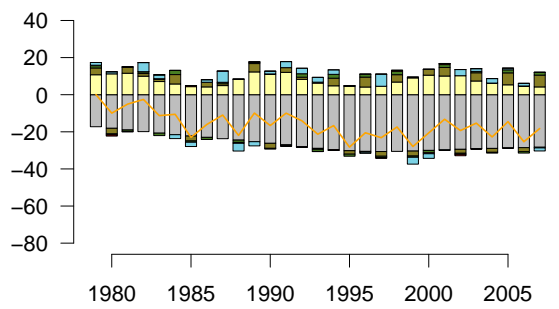

(f) $60^{\circ} \mathrm{W} 56^{\circ} \mathrm{S}$

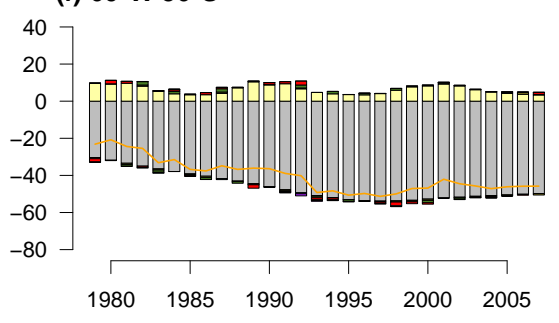

(i) $65^{\circ} \mathrm{E} 45^{\circ} \mathrm{S}$

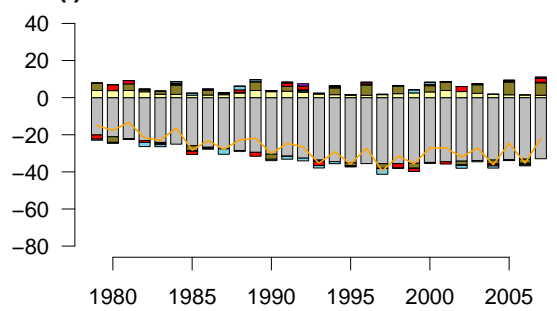

(m) $95^{\circ} \mathrm{E} 55^{\circ} \mathrm{S}$

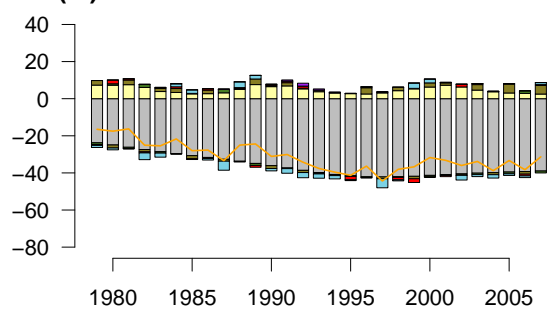

Fig. 10. Contributions of EESC (grey), solar cycle (yellow), QBO at 30 (olive) and $50 \mathrm{hPa}$ (green), AAO (red), ENSO (blue), and volcanic eruptions (purple) to long-term ozone changes (on an annual basis in DU) as derived from the $r$-largest order statistics models for EHOs (left panels (a), (d), (g), (k)), ELOs (middle panels (b), (e), (h), (l)), and as derived from the ARMA model for mean values (right panels (c), (f), (i), (m)) at selected grid cells in the southern mid-latitudes. For convenient reference the solid orange line in panels (a)-(m) gives the net contribution (sum of individual estimates) on an annual basis.

(Fig. 10k-m) the relative contribution of the dynamical covariates (ENSO, AAO, QBO) in comparison to EESC and the solar cycle is much larger for EHOs and ELOs than for mean values. While contributions of the 11-yr solar cycle at all other regions are the second dominating force after EESC, dynamics are much more important here. This can be explained by the connection between the AAO and ENSO phase and the transport of ozone rich air from the tropics to the extra-tropical regions (see above and Part 1).

\section{Discussion and conclusions}

In this study we focused on the interpretation of the spatial "fingerprints" of ENSO and volcanic eruptions in extreme and mean values of total ozone at northern and southern midlatitudes and the contribution of individual dynamical and chemical covariates to long-term total ozone changes.

The results show that the El Niño/Southern Oscillation strongly influences ozone extremes in both northern and 
southern mid-latitudes, especially during spring and towards low latitudes. This pattern suggests the enhanced transport of ozone from the tropics to the extra-tropics during strong El Niño events as discussed in earlier work (Brönnimann et al., 2004a,b; Rieder et al., 2010a,b, 2011). Further, the results show a relationship between the thickness of the southern ozone "collar" and the ENSO phase (especially La Niña) during winter at southern mid-latitudes, which is in agreement with recent work of Hitchman and Rogal (2010a,b).

The results for the volcanic eruptions of El Chichón and Mt. Pinatubo are of high interest as the "masking" of the volcanic signal at southern mid-latitudes compared to northern mid-latitudes is unexplained in the earlier literature. While results for both El Chichón and Mt. Pinatubo at northern mid-latitudes document the negative influence of the volcanic eruptions on column ozone and are in good agreement with previous studies (Staehelin et al., 1998; Fioletov et al., 2002; Mäder et al., 2007; Wohltmann et al., 2007; Harris et al., 2008; Rieder et al., 2010a,b, 2011; WMO, 2007, 2011), new insights could be gained for the Southern Hemisphere. For the eruption of El Chichón significant influence is found at lower southern mid-latitudes, which might be interpreted as "fingerprint" of the infrared heating due to the volcanic aerosol in the tropical and lower extra-tropical regions. Further the results suggest that enhanced transport of ozone from the tropics, due to the warm ENSO phase, partly compensates the chemical depletion and thereby masks the volcanic signal at southern mid-latitudes. However, a complete explanation for the absence of the volcanic signal is still missing. For the volcanic eruption of Mt. Pinatubo things are different; the results provide clear evidence that the "masking" of the Mt. Pinatubo signal at southern mid-latitudes is particularly due to atmospheric dynamics in 1991-1993. The coefficient estimates show a strong west-east gradient with strongest negative coefficient estimates towards the Antarctic Peninsula and polewards over the Southern Pacific and strongest positive coefficient estimates over the Indian Ocean. Relating the coefficient estimates and significance areas with the analysis of the position and strength of the ozone hole and ozone "collar" together with the state of the AAO provides clear evidence that the suppression of the Mt. Pinatubo signal at southern mid-latitudes is of dynamical origin. The southern polar vortex was shifted towards the Antarctic Peninsula and the southern parts of South America in 1991, the first year of the Pinatubo eruption, which might explain the negative coefficient estimates found in this region. In the following years (1992-1993) the southern ozone "collar" was displaced and richer than normal, which can be related to the negative mode of the AAO and its relation to the wave activity in tropical regions leading to a strengthening of the Lagrangian mean circulation and thereby to enhanced transport of ozone from the tropics to extra-tropics (see also Schnadt Poberaj et al., 2011) and to a strong blocking/separation between the vortex and "collar" area. Therefore the position and strength of the ozone "collar" may explain the positive coefficient es- timates found over the Indian Ocean. The clear separation between areas with enhanced ozone and reduced ozone can explain the average "zero signal" found at southern midlatitudes in previous studies (e.g., WMO, 2003, 2007, 2011; Fioletov et al., 2002), and is also visible in the analysis presented for mean values. Overall the results indicate that the Mt. Pinatubo eruption was amplified by the dynamical state of the atmosphere in the Northern Hemisphere but was strongly weakened/masked in the Southern Hemisphere.

Regarding the contribution of individual dynamical and chemical covariates to long-term total ozone changes, rather heterogeneous results have been found for northern and southern mid-latitudes, with big differences between individual regions in each hemisphere. The results show that in general ODS (in terms of EESC) are the major contributor to negative ozone trends (in extremes and mean values) at both northern and southern mid-latitudes. EESC is especially important towards higher latitudes in the Southern Hemisphere, which can probably be related to chemical ozone depletion inside the polar vortex. The major importance of EESC is in agreement with previous studies (e.g., WMO, 2003, 2007, 2011), but it is important to note that the major importance of the EESC to long-term changes may be partly amplified because EESC is the only trend variable included in the statistical models applied. After the EESC, the 11-yr solar cycle strongly contributes to long-term ozone changes. The 11-yr phase of the solar cycle can be clearly identified in the time series analysis; however, as discussed above, at central southern mid-latitudes dynamical features contribute overall more to long-term ozone changes than does the solar cycle. Although EESC and the solar cycle can be identified as major contributors to long-term ozone changes, a strong contribution of dynamical features to ozone changes is found. Strong influence of the El Niño/Southern Oscillation is found over the Northern and Southern Pacific, Central Europe, and the central southern mid-latitudes. For the North Atlantic Oscillation strong influence on column ozone is found over Labrador/Greenland, the Eastern United States, the EuroAtlantic sector, and Central Europe. For the NAO's southern counterpart, the AAO, strong influence on long-term ozone changes is found at lower southern mid-latitudes, including the southern parts of South America and the Antarctic Peninsula, and central southern mid-latitudes.

The combination of methods from EVT and standard metrics provides deeper insight into spatial patterns and the influence of atmospheric dynamics and chemistry on column ozone changes at mid-latitudes, leading to a better understanding of the net effect of the individual covariates and of their interactions.

\section{Supplementary material related to this article is available online at: http://www.atmos-chem-phys.net/13/ 165/2013/acp-13-165-2013-supplement.pdf.}


Acknowledgements. H. E. R., L. F., M. R., J. S., and A. C. D. acknowledge funding by the Competence Centre for the Environment and Sustainability (CCES) within the ETH-domain in Switzerland within the project EXTREMES: "Spatial extremes and environmental sustainability: statistical methods and applications in geophysics and the environment”. H. E. R. acknowledges also funding of the Swiss National Science Foundation through the Fellowship Grant PBEZP2-134426.

The authors are grateful to the New Zealand National Institute of Water and Atmospheric Research (NIWA) for providing the data of the NIWA assimilated total ozone data set. The authors thank Susan Solomon for thoughtful comments on an earlier version of the manuscript.

The authors are thankful to two anonymous referees for their helpful comments during the discussion phase in ACPD.

The Software $\mathrm{R}$ ( $\mathrm{R}$ Development Core Team, http: //www.R-project.org) was used for the statistical analysis.

Edited by: N. Harris

\section{References}

Alexander, M. J., Tsuda, T., and Vincent, R. A.: Latitudinal variations observed in gravity waves with short vertical wavelengths, J. Atmos. Sci., 59, 1394-1404, 2002.

Bodeker, G. E., Shiona, H., and Eskes, H.: Indicators of Antarctic ozone depletion, Atmos. Chem. Phys., 5, 2603-2615, doi:10.5194/acp-5-2603-2005, 2005.

Brasseur, G. and Granier, C.: Mount Pinatubo aerosols, chlorofluorocarbons and ozone depletion, Science, 257, 1239-1242, 1992.

Brockwell, P. J. and Davis, R. A.: Introduction to Time Series and Forecasting, Springer, New York, 2nd Edn., 2002.

Brönnimann, S., Luterbacher, J., Staehelin, J., and Svendby, T. M.: An extreme anomaly in stratospheric ozone over Europe in 1940-1942, Geophys. Res. Lett., 31, L08101, doi:10.1029/2004gl019611, 2004a.

Brönnimann, S., Luterbacher, J., Staehelin, J., Svendby, T. M., Hansen, G., and Svenoe, T.: Extreme climate of the global troposphere and stratosphere in 1940-42 related to El Niño, Nature, 431, 971-974, doi:10.1038/nature02982, 2004b.

Butler, A. H. and Polvani, L. M.: El Niño, La Niña, and stratospheric sudden warmings: A reevaluation in light of the observational record, Geophys. Res. Lett., 38, L13807, doi:10.1029/2011GL048084, 2011.

Calbó, J., Pagès, D., and González, J. A.: Empirical studies of cloud effects on UV radiation: A review, Rev. Geophys., 43, RG2002, doi:10.1029/2004rg000155, 2005.

Coles, S. G.: An Introduction to Statistical Modeling of Extreme Values, Springer, London, 2001.

Farman, J. C., Gardiner, B. G., and Shanklin, J. D.: Large losses of total ozone in Antarctica reveal seasonal $\mathrm{ClO}_{\mathrm{X}} / \mathrm{NO}_{\mathrm{X}}$ interaction, Nature, 315, 207-210, 1985.

Fioletov, V. E., Bodeker, G. E., Miller, A. J., McPeters, R. D., and Stolarski, R.: Global and zonal total ozone variations estimated from ground-based and satellite measurements: 1964-2000, J. Geophys. Res.-Atmos., 107, 4647, doi:10.1029/2001jd001350, 2002.
Fleming, E. L., Jackman, C. H., Weisenstein, D. K., and Ko, M. K. W.: The impact of interannual variability on multidecadal total ozone simulations, J. Geophys. Res.-Atmos., 112, D10310, doi:10.1029/2006jd007953, 2007.

Frossard, L., Rieder, H. E., Ribatet, M., Staehelin, J., Maeder, J. A., Di Rocco, S., Davison, A. C., and Peter, T.: On the relationship between total ozone and atmospheric dynamics and chemistry at mid-latitudes - Part 1: Statistical models and spatial fingerprints of atmospheric dynamics and chemistry, Atmos. Chem. Phys., 13, 147-164, doi:10.5194/acp-13-147-2013, 2013.

Hadjinicolaou, P., Pyle, J. A., Chipperfield, M. P., and Kettleborough, J. A.: Effect of interannual meteorological variability on mid-latitude $\mathrm{O}_{3}$, Geophys. Res. Lett., 24, 2993-2996, 1997.

Harris, N. R. P., Kyrö, E., Staehelin, J., Brunner, D., Andersen, S. B., Godin-Beekmann, S., Dhomse, S., Hadjinicolaou, P., Hansen, G., Isaksen, I., Jrrar, A., Karpetchko, A., Kivi, R., Knudsen, B., Krizan, P., Lastovicka, J., Maeder, J., Orsolini, Y., Pyle, J. A., Rex, M., Vanicek, K., Weber, M., Wohltmann, I., Zanis, P., and Zerefos, C.: Ozone trends at northern mid- and high latitudes - a European perspective, Ann. Geophys., 26, 1207-1220, doi:10.5194/angeo-26-1207-2008, 2008.

Hegglin, M. I. and Shepherd, T. G.: Large climate-induced changes in ultraviolet index and stratosphere-to-troposphere ozone flux, Nat. Geosci., 2, 687-691, doi:10.1038/ngeo604, 2009.

Hitchman, M. H. and Rogal, M. J.: Influence of tropical convection on the Southern Hemisphere ozone maximum during the winter to spring transition, J. Geophys. Res.-Atmos., 115, D14118, doi:10.1029/2009jd012883, 2010a

Hitchman, M. H. and Rogal, M. J.: ENSO influences on Southern Hemisphere column ozone during the winter to spring transition, J. Geophys. Res.-Atmos., 115, D20104, doi:10.1029/2009jd012844, 2010b.

Hood, L. L. and Soukharev, B. E.: Interannual variations of total ozone at northern midlatitudes correlated with stratospheric EP flux and potential vorticity, J. Atmos. Sci., 62, 3724-3740, 2005.

Koch, G., Wernli, H., Schwierz, C., Staehelin, J., and Peter, T.: A composite study on the structure and formation of ozone miniholes and minihighs over Central Europe, Geophys. Res. Lett., 32, L12810, doi:10.1029/2004g1022062, 2005.

Kodera, K.: Influence of volcanic eruptions on the troposphere through stratospheric dyanamical processes in the northernhemisphere winter, J. Geophys. Res.-Atmos., 99, 1273-1282, 1994.

Koike, M., Jones, N. B., Matthews, W. A., Johnston, P. V., McKenzie, R. L., Kinnison, D., and Rodriguez, J.: Impact of Pinatubo aerosols on the partitioning between $\mathrm{NO}_{2}$ and $\mathrm{HNO}_{3}$, Geophys Res. Lett., 21, 597-600, 1994.

Labitzke, K. and van Loon, H.: The Stratosphere: Phenomena, History, and Relevance, Springer, Berlin, 1999.

Lin, P., Fu, Q., Solomon, S., and Wallace, J. M.: Temperature trend patterns in Southern Hemisphere high latitudes: novel indicators of stratospheric change, J. Climate, 22, 6325-6341, doi:10.1175/2009jcli2971.1, 2009.

Mäder, J. A., Staehelin, J., Brunner, D., Stahel, W. A., Wohltmann, I., and Peter, T.: Statistical modeling of total ozone: selection of appropriate explanatory variables, J. Geophys. Res.-Atmos., 112, D11108, doi:10.1029/2006jd007694, 2007.

Mariotti, A., Mechoso, C. R., Legras, B., and Daniel, V.: The evolution of the ozone "collar" in the Antarctic lower stratosphere 
during early August 1994, J. Atmos. Sci., 57, 402-414, 2000.

Müller, R., Grooß, J.-U., Lemmen, C., Heinze, D., Dameris, M., and Bodeker, G. E.: Simple measures of ozone depletion in the polar stratosphere, Atmos. Chem. Phys., 8, 251-264, doi:10.5194/acp8-251-2008, 2008.

Newman, P. A., Nash, E. R., and Rosenfield, J.: What controls the temperature of the arctic stratosphere during the spring?, J. Geophys. Res., 106, 19999-20010, 2001.

Orsolini, Y. J. and Doblas-Reyes, F. J.: Ozone signatures of climate patterns over the Euro-Atlantic sector in the spring, Q. J. Roy. Meteorol. Soc., 129, 3251-3263, doi:10.1256/qj.02.165, 2003.

Orsolini, Y. J. and Limpasuvan, V.: The North Atlantic Oscillation and the occurrences of ozone miniholes, Geophys. Res. Lett., 28, 4099-4102, 2001.

Peter, T.: Microphysics and heterogeneous chemistry of polar stratospheric clouds, Annu. Rev. Phys. Chem., 48, 785-822, 1997.

Polvani, L. M., Waugh, D. W., Correa, G. J. P., and Son, S.-W.: Stratospheric ozone depletion: the main driver of 20th century atmospheric circulation changes in the Southern Hemisphere?, J. Climate, 24, 795-812, 2011.

Randel, W. J., Wu, F., and Stolarski, R.: Changes in column ozone correlated with the stratospheric EP flux, J. Meteorol. Soc. Jpn., 80, 849-862, 2002.

Rieder, H. E., Staehelin, J., Maeder, J. A., Peter, T., Ribatet, M., Davison, A. C., Stübi, R., Weihs, P., and Holawe, F.: Extreme events in total ozone over Arosa - Part 1: Application of extreme value theory, Atmos. Chem. Phys., 10, 10021-10031, doi:10.5194/acp-10-10021-2010, 2010a.

Rieder, H. E., Staehelin, J., Maeder, J. A., Peter, T., Ribatet, M., Davison, A. C., Stuibi, R., Weihs, P., and Holawe, F.: Extreme events in total ozone over Arosa - Part 2: Fingerprints of atmospheric dynamics and chemistry and effects on mean values and long-term changes, Atmos. Chem. Phys., 10, 10033-10045, doi:10.5194/acp-10-10033-2010, 2010 b.

Rieder, H. E., Jancso, L. M., Di Rocco, S., Staehelin, J., Maeder, J. A., Peter, T., Ribatet, M., Davison, A. C., De Backer, H., Koehler, U., Krzyścin, J., and Vaníček, K.: Extreme events in total ozone over the northern mid-latitudes: an analysis based on long-term data sets from five European ground-based stations, Tellus B, 63, 860-874, doi:10.1111/j.1600-0889.2011.00575.x, 2011.

Sato, M., Hansen, J. E., McCormick, M. P., and Pollack, J. B.: Stratospheric aerosol optical depths, 1850-1990, J. Geophys. Res.-Atmos., 98, 22987-22994, 1993.

Schnadt Poberaj, C., Staehelin, J., and Brunner, D.: Missing stratospheric ozone decrease at Southern Hemisphere middle latitudes after Mt. Pinatubo: a dynamical perspective, J. Atmos. Sci., 68, 1922-1945, 2011.

Shepherd, T. G.: Dynamics, stratospheric ozone, and climate change, Atmos.-Ocean, 46, 117-138, doi:10.3137/ao.460106, 2008.

Solomon, S.: Stratospheric ozone depletion: a review of concepts and history, Rev. Geophys., 37, 275-316, 1999.
Staehelin, J., Kegel, R., and Harris, N. R. P.: Trend analysis of the homogenized total ozone series of Arosa (Switzerland), 19261996, J. Geophys. Res.-Atmos., 103, 8389-8399, 1998.

Steinbrecht, W., Haßler, B., Brühl, C., Dameris, M., Giorgetta, M. A., Grewe, V., Manzini, E., Matthes, S., Schnadt, C., Steil, B., and Winkler, P.: Interannual variation patterns of total ozone and lower stratospheric temperature in observations and model simulations, Atmos. Chem. Phys., 6, 349-374, doi:10.5194/acp6-349-2006, 2006.

Stolarski, R. S., Douglass, A. R., Steenrod, S., and Pawson, S.: Trends in stratospheric ozone: lessons learned from a 3D chemical transport model, J. Atmos. Sci., 63, 1028-1041, 2006.

Struthers, H., Bodeker, G. E., Austin, J., Bekki, S., Cionni, I., Dameris, M., Giorgetta, M. A., Grewe, V., Lefèvre, F., Lott, F., Manzini, E., Peter, T., Rozanov, E., and Schraner, M.: The simulation of the Antarctic ozone hole by chemistry-climate models, Atmos. Chem. Phys., 9, 6363-6376, doi:10.5194/acp-9-63632009, 2009.

Telford, P., Braesicke, P., Morgenstern, O., and Pyle, J.: Reassessment of causes of ozone column variability following the eruption of Mount Pinatubo using a nudged CCM, Atmos. Chem. Phys., 9, 4251-4260, doi:10.5194/acp-9-4251-2009, 2009.

Thompson, D. W. J. and Solomon, S.: Understanding recent stratospheric climate change, J. Climate, 22, 1934-1943, doi:10.1175/2008jcli2482.1, 2009.

Thompson, D. W. J. and Wallace, J. M.: Annular modes in the extratropical circulation. Part I: month-to-month variability, J. Climate, 13, 1000-1016, 2000.

Trenberth, K. E., Branstator, G. W., Karoly, D., Kumar, A., Lau, N. C., and Ropelewski, C.: Progress during TOGA in understanding and modeling global teleconnections associated with tropical sea surface temperatures, J. Geophys. Res.-Oceans, 103, 1429114324, 1998.

van Loon, H. and Labitzke, K.: The Southern Oscillation. Part V: The anomalies in the lower stratosphere of the Northern Hemisphere in winter and a comparison with the Quasi-Biennial Oscillation, Mon. Weather Rev., 115, 357-369, 1987.

Vyushin, D., Fioletov, V. E., and Shepherd, T. G.: Impact of longrange correlations on trend detection in total ozone, J. Geophys. Res., 112, D14307, doi:10.1029/2006JD008168, 2007.

WMO: Scientific Assessment of Ozone Depletion: 2002, Global Ozone Research and Montitoring Project - Report No. 47, World Meteorological Organization, Geneva, 2003.

WMO: Scientific Assessment of Ozone Depletion: 2006, Global Ozone Research and Montitoring Project - Report No. 50, World Meteorological Organization, Geneva, 2007.

WMO: Scientific Assessment of Ozone Depletion: 2010, Global Ozone Research and Montitoring Project - Report No. 52, World Meteorological Organization, Geneva, 2011.

Wohltmann, I., Lehmann, R., Rex, M., Brunner, D., and Mäder, J. A.: A process-oriented regression model for column ozone, J. Geophys. Res.-Atmos., 112, D12304, doi:10.1029/2006jd007573, 2007. 